\title{
Insulin autoantibodies are associated with islet cell antibodies; their relation to insulin antibodies and B-cell function in diabetic children
}

\author{
J.Ludvigsson ${ }^{1}$, C. Binder ${ }^{2}$ and T.Mandrup-Poulsen ${ }^{2}$ \\ ${ }^{1}$ Department of Paediatrics, University Hospital, Linköping, Sweden, and \\ ${ }^{2}$ Steno Memorial Hospital, Hagedorn Research Laboratory, Gentofte, Denmark
}

\begin{abstract}
Summary. Blood was drawn from 74 children, 3-16 years old, at diagnosis of Type 1 (insulin-dependent) diabetes and before the first insulin injection. Insulin autoantibodies were detected with a polyethylen-glycol-method in $27 / 74$ (36.4\%) and with an immuno-electrophoretic method in 6/74 (8.1\%). Islet cell cytoplasmic antibodies detected by indirect immuno-fluorescence were found in $49 / 74$ patients $(66.2 \%)$, who included as many as 23 of the 27 patients with insulin autoantibodies determined with the polyethylen-glycolmethod $(p<0.01)$. The proportion of insulin autoantibodypositive patients who developed insulin antibodies during the first 9 months of insulin treatment was not significantly greater $(51.8 \%)$ than that of insulin autoantibody-negative patients (44.6\%), but patients with both islet cell antibodies and insulin autoantibodies at diagnosis produced more insulin antibodies during the first 9 months $(p<0.05)$. There was no difference in fasting or meal stimulated serum Cpeptide after 3,9 or 18 months as related to occurrence of
\end{abstract}

insulin autoantibodies and/or islet cell antibodies. The correlation between insulin autoantibodies and islet cell antibodies indicates that both types of autoantibodies reflect the same immunological process, although the lack of correlation to C-peptide may indicate that they play a minor causal role. In addition, the results show that patients with an active autoimmune process evidently tend to produce more insulin antibodies during the first months of insulin treatment, but the islet cell antibodies and insulin autoantibodies-positive patients had at least as good residual B-cell function as patients without autoantibodies at diagnosis. If insulin antibodies produced as a response to exogenous insulin do have a negative effect on B-cell function our present results suggest that such mechanisms are of minor importance.

Key words: Insulin autoantibodies, islet cell antibodies, insulin antibodies, C-peptide, children, Type 1 (insulin-dependent) diabetes.
Several types of autoantibodies reactive with pancreatic islet cells can be found in serum of newly-diagnosed diabetic patients [1]. In other autoimmune diseases of endocrine organs autoantibodies against not only the hormone-producing cells, but also against the produced hormone are often found [2], but in diabetes mellitus autoantibodies against insulin have not been demonstrated until recently $[3,4]$. The role of these autoantibodies is even more unclear than that of islet cell autoantibodies, as some authors have found no relation to other autoantibodies or HLA-types [4-7]; these autoantibodies also have been found even more commonly in non-diabetic twins of diabetic patients than in diabetic patients themselves [4]. Insulin autoantibodies have also been found in as many as $81 \%$ of patients after chickenpox infection, indicating that viral infections may trigger the production of insulin autoantibodies (IAA) by a mechanism involving polyclonal immunocyte activation [8]. However, insulin autoantibodies in the pre-diabetic period have in other studies been correlated both to insulin-receptor antibodies [9] and to islet cell antibodies [10, 11]. It has even been suggested that insulin autoantibodies together with complement fixing islet cell antibodies (CF-ICA) confer more risk for future development of diabetes than the presence of either marker alone [10, 11] and we therefore decided to analyse whether newly-diagnosed diabetic patients with islet cell antibodies and insulin autoantibodies lose their B-cell function more rapidly than patients without such autoantibodies.

Insulin antibodies in response to exogenous insulin is a common phenomenon. Their clinical importance is unclear but studies have indicated that insulin antibodies have a negative effect on the metabolic balance and on the duration of the metabolically stable period early after diagnosis, the so-called partial remission [12-14]. It has been shown that even very low concentrations of insulin antibodies are related to a diminished residual insulin secretion and an increased requirement of insulin at 9 months duration of diabetes [15]. Although the injection of insulin antibodies are able to cause glucose intolerance and even diabetes in experimental animals [16-19] the inverse correlation 
between low levels of insulin antibodies and C-peptide secretion remains obscure. One explanation could be that those patients who develop insulin antibodies against exogenous insulin and lose residual insulin secretion are simply those patients who already at diagnosis have insulin autoantibodies as part of an ongoing destructive autoimmune process. Another explanation could be that immune recognition of insulin as an autoantigen could prime the individual to produce antibodies to exogenous insulin. One purpose of this study was to further clarify this question.

\section{Subjects and methods}

In the years $1980-84$ we studied 74 children, 39 boys and 35 girls, aged 3-16 years (mean 9.1 \pm SD 3.9) at the diagnosis of Type 1 (insulin-dependent) diabetes. All patients were treated with a combination of short- and intermediate-acting insulin 2-4 times daily. Most received monocomponent porcine insulin but some of them received semisynthetic human insulin (Novo) when these insulins appeared on the market. All patients except 4, went into a period with stable metabolism with normal or near normal glycosylated haemoglobin and/or no or minimal glucosuria in daily tests of single-voided urine. Later, usually within a year, the insulin requirement increased and the metabolism became gradually less stable. Blood was drawn before the first insulin injection and then at 3,9 and 18 months duration. Serum was stored at $-20^{\circ} \mathrm{C}$. The serum was analysed for insulin antibodies with Christiansen's method (detection limit $0.05 \mu / 1$ ) [20] and with a competitive binding assay using monoiodinated insulin as marker and polyethylen-glycol (PEG) as precipitating agent. Insulin antibodies were only considered present if precipitated radioactivity exceeded non-specific binding and if this radioactivity bound could be suppressed significantly by addition of $25 \mu / 1$ of unlabelled insulin [21]. The method has been part of the Immunology and Diabetes Workshops programme. The four possible iodinations of insulin $\left(A_{14}, A_{19}, B_{16}\right.$ and $\left.B_{26}\right)$ were used in all antibody positive samples to find out whether the affinity differed, but this was not the case. Variance in specificity of binding was tested by adding $25 \mathrm{U} / 1$ of porcine, human, and bovine insulin to different tubes. As there is no method that discriminates between IAA and insulin antibodies (IA), we regard everything determined after initiation of insulin therapy as IA (although we will sometimes call them PEG-IA to underline the method used for determination). Fasting serum Cpeptide and the maximal response to a standardised breakfast was determined at 3,9, and 18 months after diagnosis by the method of Heding [22] in 58 patients. Sixteen patients, most of them referred from a neighbouring hospital, did not wish to participate in this follow-up.

Islet cell cytoplasmatic antibodies (ICA) were determined by indirect immunofluorescence on cryostat sections of one blood group 0 human pancreatic specimen, as described in detail elsewhere [23]. All serum samples were read blind and independently by two readers. The inter-reader coefficient of variation was 7\%. In case of reader disagreement the serum sample was re-tested in an independent assay until agreement was obtained. Every assay contained positive and negative control sera at different dilutions, which were also read blind. The specificity of the pancreatic specimen used (i.e. the number of times the negative control serum was read negative, as the percentage of the number of times the sample was read) was $100 \%$ based on 244 readings. The sensitivity of the specimen (i.e. the number of times as positive diabetic control serum diluted $1: 3$ or $1: 27$ was read as positive as a percentage of the number of times the sample was read in these dilutions) was $96 \%$ based on 264 determinations on the actual pancreas. We have actively participated in the Juvenile Diabetes Foundation (JDF) International Workshops on the Standardisation of ICA [24] and were classified as an "A-labora- tory" at the third workshop held November 1987 in New York, USA. Blind testing of the JDF positive ICA standard serum diluted in PBS resulted in a linear dilution curve, with a cut-off point of $5 \mathrm{JDF} \mathrm{U} / \mathrm{ml}$. When testing a number of coded test sera in duplicate assay sensitivity and specificity was found to be $64 \%$ and $98 \%$ respectively. Assay precision expressed as the variance of double determinations of positive sera was 0.64 . When plotting our titres for these coded sera against the assigned values the regression coefficient was 0.95 . The possibility that binding of IAA to cytoplasmic insulin in B cells should result in a staining pattern read as a false positive reaction for ICA can be excluded. First, several sera were identified which were IAA positive but ICA negative (see Results). Second, B-cell selective binding in the serum samples was examined by a two-colour immuno-fluorescence technique with double staining of the pancreatic sections with a specific monoclonal antibody against human proinsulin, which does not cross-react with human insulin [25]. The following sera were compared in a blinded fashion: IAA positive/ICA positive, IAA negative/ICA positive; IAA positive/ICA negative, and IAA negative/ICA negative sera from newly diagnosed Type 1 patients not treated with exogeneous insulin.

Proinsulin, as well as non-proinsulin staining islet cells in sections incubated with IAA negative/ICA negative, or IAA positive/ICA negative sera from patients with insulin dependent diabetes were consistently read as negative for ICA. IAA positive/ICA positive sera stained not only proinsulin-containing islet cells, but also all other islet cells, and did not show a different staining pattern of the islets as compared to IAA negative/ICA positive sera.

Finally, preabsorbtion of recent onset insulin-dependent diabetes sera with excess human insulin did not influence the end-point titres of ICA [26].

\section{Statistical analysis}

$\mathrm{Chi}^{2}$-test and Wilcoxon Rank Sum Test were used in the comparison between groups. When following changes with time within a certain group Wilcoxon's Test for paired differences was used. A $p$-value of 0.05 (two-tailed) was accepted as level of significance.

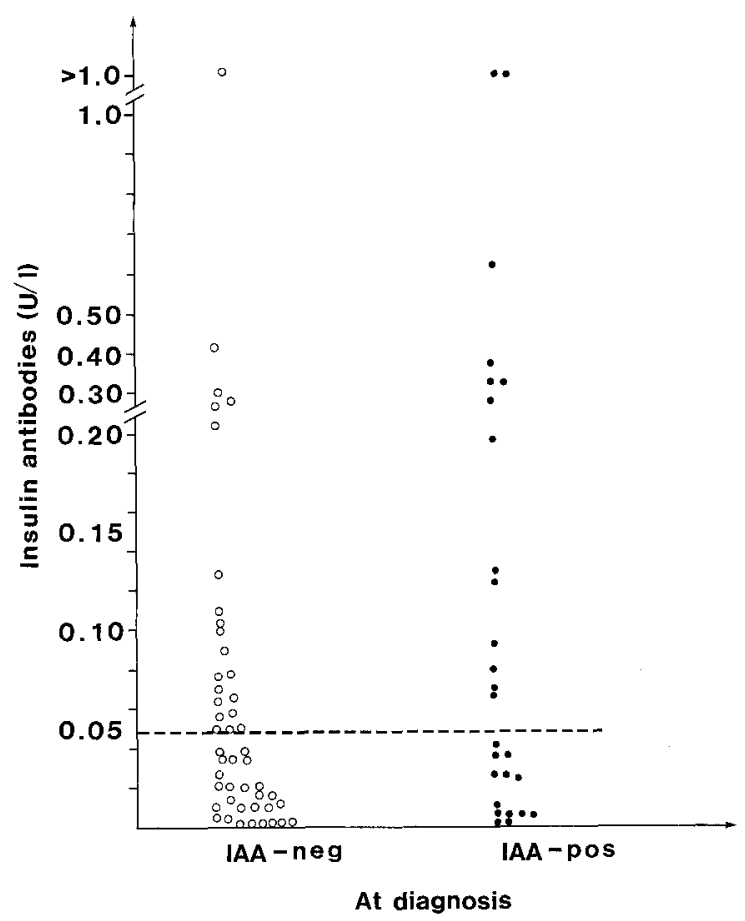

Fig. 1. Insulin antibodies towards exogenous insulin in relation to Insulin autoantibodies (IAA) at diagnosis. -----= detection limit 
Table 1. Production of insulin antibodies (IA) in relation to autoantibodies (ICA and IAA) at diagnosis

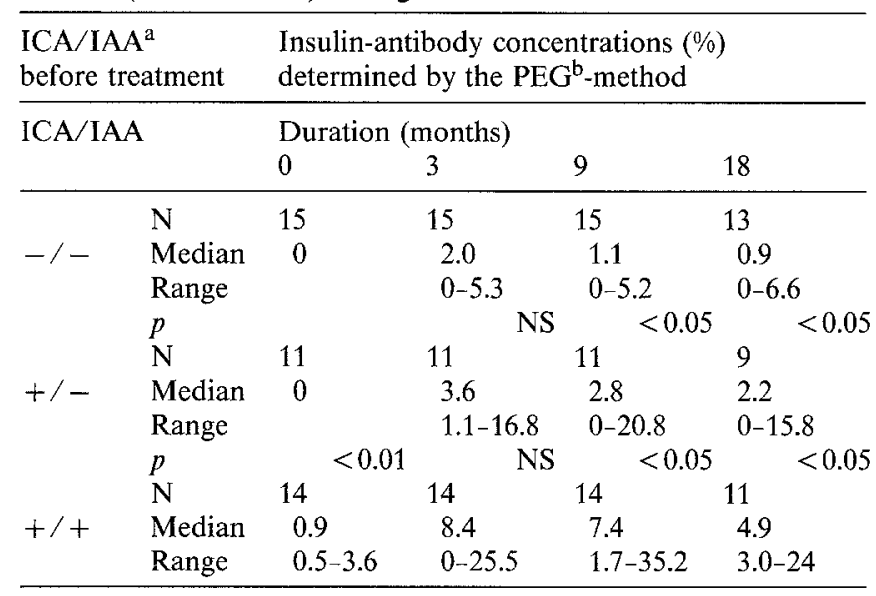

a Islet cell antibodies (ICA)

${ }^{b}$ Polyethylen-glycol (PEG) method

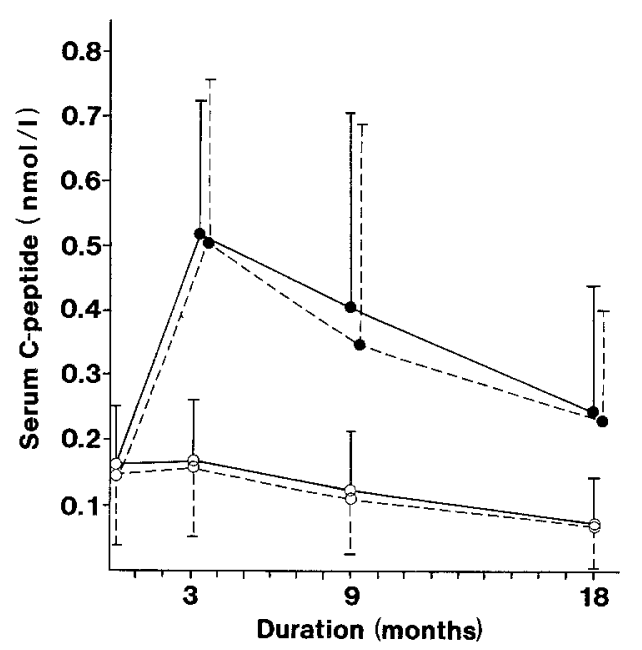

Fig. 2. Serum C-peptide during the first 18 months of diabetes in relation to insulin autoantibodies (IAA) at diagnosis. $\bigcirc-\cdots=$ fasting C-peptide (mean $\pm \mathrm{SD}$ ) in patients IAA-negative at diagnosis; $\delta-\delta=$ fasting C-peptide in IAA-positive patients; $-{ }_{-}=$maximal $C$-peptide (mean \pm SD) response to a standardised breakfast in IAA-negative patients; $\boldsymbol{D}=$ maximal $\mathrm{C}$ peptide response in IAA-positive patients

\section{Results}

At diagnosis IAA were found in $27 / 74$ (36.4\%) patients with the PEG-method but only in 4 of these 27 , plus in another 2 with Christiansen's method 6/74 (8.1\%). IAA determined with the PEG-method were found in $15 / 34$ girls (44\%) and in $12 / 40$ boys $(30 \%)$ (NS). The mean age at diagnosis was 8.5 (median 9) years for those with and 9.9 (median 9) years in those without IAA (NS) ICA were found in $49 / 74$ patients at diagnosis $(66.2 \%)$ including $23 / 27$ patients with IAA demonstrated with the PEG-method $(p<0.01)$.

Among the 27 IAA-positive 14 (51.8\%) developed IA detectable with Christiansen's method within the first 9 months of diabetes compared to $21 / 47$ (44.6\%) of those who were PEG-IAA-negative at diagnosis

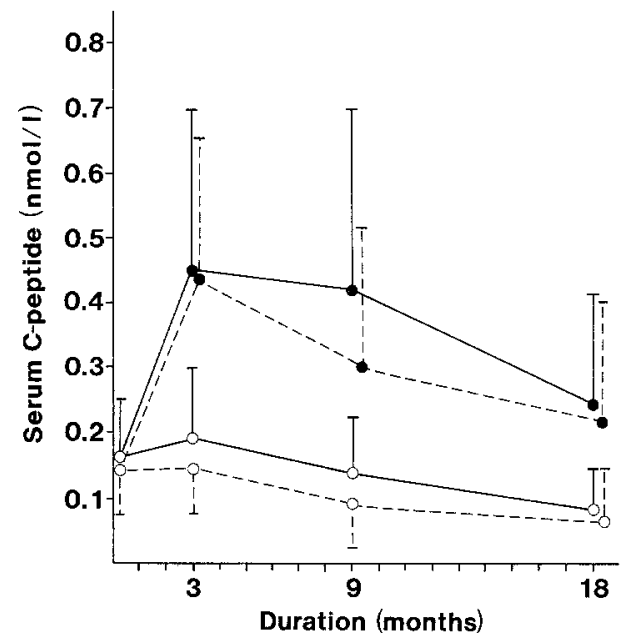

Fig. 3. Serum C-peptide during the first 18 months of diabetes in relation to islet cell antibodies (ICA) at diagnosis. $\bar{O}---\delta=$ fasting $C$ peptide (mean $\pm \mathrm{SD}$ ) in patients IAA-negative at diagnosis; $\bar{O}=$ fasting C-peptide in IAA--positive patients; $--{ }^{-}=$maximal $C$-peptide (mean $\pm S D$ ) response to a standardised breakfast in IAA-negative patients; $=$ maximal $C$ peptide response in IAA-positive patients

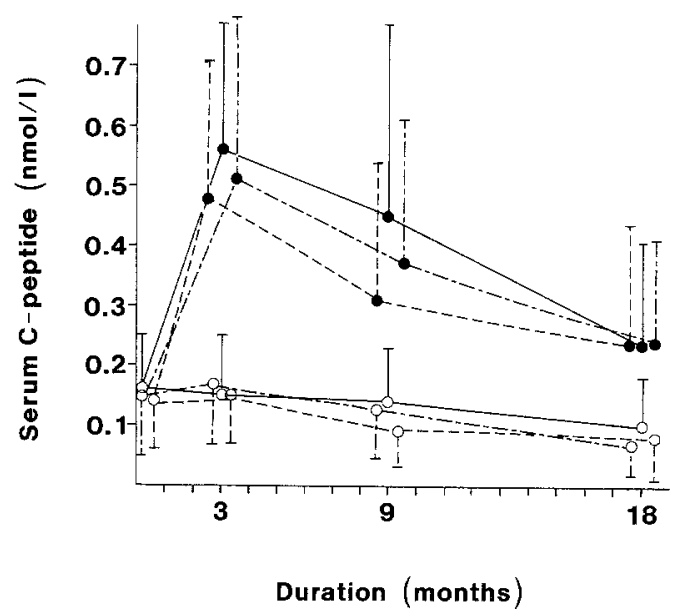

Fig.4. Residual B-cell function in relation to islet cell antibodies (ICA) and autoantibodies (IAA). $\delta---\delta=$ fasting serum C-peptide $($ mean $\pm \mathrm{SD})$ in ICA negative/IAA negative patients; $\bar{O}--\bar{\delta}=$ fasting C-peptide in ICA positive/IAA negative patients; $\bar{O}-\bar{O}=$ fasting C-peptide in ICA positive/IAA positive patients; - maximal C-peptide response to a standardised breakfast in ICA negative/IAA negative patients; $\overline{-}-\overline{\mathbf{O}}=$ maximal $\mathrm{C}$-peptide response in ICA positive/IAA negative patients; - maximal C-peptide response in ICA positive/IAA positive patients

(NS) (Fig. 1). Only 8/25 (32\%) of ICA-negative patients produced IA within the same period compared to $26 / 49(53.1 \%)$ of the ICA-positive patients $(p<0.10) .14 / 23(60.9 \%)$ patients with both positive ICA and positive IAA at diagnosis developed IA but only $6 / 21(28.6 \%)$ of the ICA-IAA-negative patients $(p<0.05)$. Serum samples were available to determine IA with the PEG-method at both 3 and 9 months duration in 40 patients and in 33 also at 18 months duration. PEG-IA were found in $39 / 40$ patients already after 3 months. In those both ICA-positive and IAA- 
positive already at diagnosis the values increased to 3 months duration $(p<0.01)$ (Table 1$)$. In this group which had the same mean age ( 8.5 years) as other patients, 9/14 also had measurable IA with Christiansen's method compared to $0 / 15$ after 3 months duration in the patients with neither ICA nor IAA at diagnosis $(p<0.001)$.

There was no difference in serum C-peptide at diagnosis, either between patients with or without IAA or between patients with and without ICA. During a follow-up period of 18 months there was still no difference in fasting serum C-peptide or in the maximal response to a standardised breakfast (Fig. 2 and Fig.3). When we divided the patients into those who had both detectable ICA and IAA at diagnosis and compared their C-peptide values with those patients who had no detectable autoantibodies at diagnosis, we saw no difference (Fig. 4).

\section{Discussion}

Our results confirm that newly-diagnosed diabetic children irrespective of age quite frequently exhibit autoantibodies against insulin $[3,4,27]$. This is found with the very sensitive PEG-method while only a few patients with insulin antibodies before any treatment could be found with Christiansen's method. In contrast to others $[4,5,27,28]$ we have found a significant correlation between ICA and IAA. Thus, it is likely that IAA are produced as part of the activation of the humoral immune system against B-cell antigens leading to the production of other autoantibodies found in newly diagnosed Type 1 diabetic patients. However, since patients with IAA at diagnosis had the same Cpeptide secretion at 3,9 as well as at 18 months as those without IAA, these autoantibodies do not seem to play a very active causal role in B-cell destruction [27]. This is in agreement with the common findings of IAA in healthy twins of diabetic patients $[4,29]$, and with studies of humoral autoimmunity related to remission induced with immunosuppressive agents [30]. Previous studies of the relation between humoral autoimmunity and B-cell function [31] have shown that ICA may be markers of a more rapid decrease in Cpeptide secretion when followed prospectively from diagnosis up to 30 months of diabetes duration; but in the present follow-up of diabetic children for 18 months this cannot be confirmed. On the contrary, ICA-positive patients tend to have a slightly better insulin secretion at 9 months duration in agreement with the findings of Mustonen et al. [32]. One explanation of this could be that patients with a residual B-cell mass also have antigen to stimulate the production of islet cell antibodies, whilst among patients without a residual B-cell mass some patients lack ICA because most B cells have disappeared. Others have suggested that the combination of positive islet cell antibodies with positive insulin autoantibodies might be a better marker of the B-cell destructive process [11]. However, we were unable to demonstrate a more rapid loss of Bcell function in patients with both these autoantibodies at diagnosis. As we have used a standardised breakfast as load we have avoided the errors related to actual metabolic control seen when a glucagon test is used; therefore, our evaluation of B-cell function should be reasonably reliable.

The present study also shows that with a sensitive method every diabetic child can be shown to form insulin antibodies already within 3 months treatment with exogenous insulin. This antibody production seems to be more common and more pronounced among patients with autoantibodies especially if they have both ICA and IAA, which has not been shown before. A majority of this group of patients have insulin antibodies measurable even with Christiansen's method already after 3 months duration. Thus, early production of insulin antibodies seems at least to some extent to be part of an ongoing autoimmune process [33]. This finding would have been a plausible explanation for the inverse correlation shown between insulin antibodies and residual B-cell function [15] if these autoantibody-positive patients also had lost their Bcell function more rapidly than other patients, but that was not the case in the present study. However, it is of course still possible that such patients with an active autoimmune process not only produce insulin antibodies easier, but also lose their residual insulin secretion more rapidly. Not only an ongoing autoimmune process, but also the immunogenicity of exogenous insulin certainly plays an important role in insulin antibody production. This is confirmed by our results showing a rapid increase in insulin antibodies in all patients within a few months of treatment with exogenous insulin. It cannot be excluded that insulin antibodies produced as a response to exogenous insulin might add to an ongoing immune destruction of the B cells. However, although insulin antibodies may stress the B cells $[34,35]$ and could make the B cells more susceptible to noxious agents, our results suggest that such mechanisms are of minor importance.

Acknowledgement. Thanks to the technicians Ms. Bergman, Ms. Bille and Ms. Kjellberg for their skillful and enthusiastic work. This study was supported by Swedish Medical Council B8319X-04528-09, Swedish Diabetes Association and Novo Research Institute. TMP is a recipient of a research grant from the Michaelsen Foundation, and received financial support from the Danish Diabetes Association and Nordisk Insulinlaboratorium.

\section{References}

1. Lernmark $\AA$, Baekkeskov S (1981) Islet cell antibodies - theoretical and practical implications. Diabetologia 21: 431-435

2. Irvine I, Clarke BF, Scarth L, Culle DR, Duncan LJP (1970) Thyroid and gastric autoimmunity in patients with diabetes mellitus. Lancet II: 163-168 
3. Palmer JP, Asplin CM, Clemons P, Lyzenk K, Tatpati O, Raghu PK, Paquette TL (1983) Insulin antibodies in insulin-dependent diabetics before insulin treatment. Science 222: 1337-1339

4. Wilkin T, Armitage M, Casey C, Pyke DA, Hoskins PJ, Rodier M, Diaz J-L, Leslie RDG (1985) Value of insulin autoantibodies as serum markers for insulin-dependent diabetes mellitus. Lancet II: $480-481$

5. Dean BM, Walker R, Bone AJ, Cooke A, Baird JD (1985) Predicting and preventing insulin-dependent diabetes mellitus. Lancet II: 1043

6. Wilkin TJ, Scott-Morgan L, Diaz J-L, Casey CR, Armitage M, Betts $P$ (1986) The relationship between insulin autoantibodies (IAA) and islet cell antibodies (ICA) as serological markers for type I diabetes in Man and the BB rat. Diabetes [Suppl] 35: 87 a

7. Sochett E, McVey M, Yoon J-W, Daneman D (1986) Insulin antibodies in IDDM children before insulin therapy: relationship to islet cell antibodies, C-peptide and antibody response to human insulin. Diabetes [Suppl] 35: 93 a

8. Bodansky HJ, Dean BM, Bottazzo GF, Grant PJ, McNally J, Hambling MH (1986 Vol II) Islet-cell antibodies and insulin autoantibodies in association with common viral infections. The Lancet No 8520: 1351-1353

9. Ludwig SM, Faiman C, Dean HJ (1987) Insulin and insulin-receptor autoantibodies in children with newly diagnosed IDDM before insulin therapy. Diabetes 36: 420-425

10. Dean BM, Becker F, McNally JM, Tarn AC, SchwartzG, Gale EAM, Bottazzo GF (1986) Insulin autoantibodies in the pre-diabetic period: correlation with islet cell antibodies and development of diabetes. Diabetologia 29: 339-342

11. Atkinson MA, Fisk DD, Spillar RP, MacLaren NK (1986) Insulin antibodies as markers for insulin dependent diabetes mellitus (IDD). Diabetes [Suppl] 35: 87 a

12. Andersen OO (1975) The immunogenic properties of highly purified insulin preparations. The clinical importance of insulinbinding antibodies. Acta Endocrinol 78: 723-735

13. Ludvigsson J (1977) Sociophysiological factors and metabolic control in juvenile diabetes. Acta Paediatr Scand 66: 431-437

14. Ludvigsson J, Heding LG, Larsson Y, Leander E (1977) C-peptide in juvenile diabetics beyond the postinitial remission period. Relation to clinical manifestations at onset of diabetes, remission and diabetic control. Acta Paediatr Scand 55: 177-184

15. Ludvigsson J (1984) Insulin antibodies in diabetic children treated with monocomponent porcine insulin from the onset: relationship to B-cell function and partial remission. Diabetologia 26: $138-141$

16. Freytag G, Jansen FK, Klöppel G (1973) Reactions to fractions of crystalline insulin. Diabetologia 9: 185-190

17. Grodsky GM, Feldman R, Toreson WE, Lee JC (1966) Diabetes mellitus in rabbits immunized with insulin. Diabetes $15: 579-585$

18. Jansen FK, Freytag G (1973) Immune reactions to fractions of crystalline insulin. Diabetologia 9: 191-196

19. Klöppel G (1975) 'Insulin' induced insulitis. Acta Endocrinol (Copenh) [Suppl] 205: 107-119

20. Christiansen AH (1973) Radioimmunoelectrophoresis in the determination of insulin binding to IgG. Methodological studies. Horm Metab Res 5: 147-154

21. Pramming S, Lauritzen T, Thorsteinsson B, Johansen K, Binder C (1984) Absorption of soluble and isophane semi-synthetic human and porcine insulin in insulin-dependent diabetic subjects. Acta Endocrinol 105: 215-220
22. Heding LG (1975) Radioimmunological determination of human C-peptide in serum. Diabetologia 11: $541-548$

23. Marner B, Lernmark $\AA$, Nerup J, Molenaar JL, Tuk C, Bruining CJ (1983) Analysis of islet cell antibodies on frozen sections of human pancreas. Diabetologia 25: 93-96

24. Botazzo GF, Gleichman H (1986) Immunology and diabetes workshops: report of the first international workshop on the standardisation of cytoplasmic islet cell antibodies. Diabetologia 29: $125-126$

25. Madsen OD, Olsson ML, Bille G, Sundquist G, Lernmark $\AA$, Dahlquist G, Ludvigsson J (1986) A two-colour immunofluorescence test with a monoclonal human proinsulin antibody improves the assay for islet cell antibodies. Diabetologia 29: 115-118

26. Olsson ML, Sundquist G, Lernmark $\AA$ (1987) Prolonged incubation in the two-colour immunofluorescence test increases the prevalence and titres of islet cell antibodies in Type 1 (insulin-dependent) diabetes mellitus. Diabetologia 30: 327-332

27. Arslanian SA, Becker DJ, Rabin R, Athison R, Eberhardt M, Cavender D, Dorman J, Drash AL (1985) Correlates of insulin antibodies in newly diagnosed children with insulin-dependent diabetes before insulin therapy. Diabetes 34: 926-930

28. Karjalainen J, Knip M, Mustonen A, Ilonen J, Åkerblom HK (1986) Relation between insulin antibody and complement-fixing islet cell antibody at clinical diagnosis of IDDM. Diabetes 35: $620-622$

29. Srikanta S, Ricker AT, McCulloch DK, Soeldner JS, Eisenbarth GS, Palmer JP (1986) Autoimmunity to insulin, beta cell dysfunction and development of insulin-dependent diabetes mellitus. Diabetes 35: 139-142

30. Mandrup-Poulsen T, Nerup J, Stiller CR, Marner B, Bille G, Heinrichs D, Martell R, Dupre J, Keown PA, Jenner MR, Rodger N, Wolfe B, Graffenried BV, Binder C (1985) Disappearance and reappearance of islet cell cytoplasmic antibodies in cyclosporin-treated insulin-dependent diabetics. Lancet I: 599-602

31. Marner B, Agner T, Binder C et al. (1985) Increased reduction in fasting C-peptide is associated with islet-cell antibodies in Type 1 (insulin-dependent) diabetic patients. Diabetologia 28: 875-880

32. Mustonen A, Knip M, Huttunen N-P, Puuka R, Käär M-L, Åkerblom HK (1984) Evidence of delayed B-cell destruction in Type 1 (inslin-dependent) diabetic patients with persisting complement-fixing cytoplasmic islet-cell antibodies. Diabetologia 27: $421-426$

33. McEvoy RC, Witt ME, Ginsberg-Fellner F, Rubinstein P (1986) Anti-insulin antibodies in children with type I diabetes mellitus. Diabetes 35: 634-640

34. Wright PJ (1961) The production of experimental diabetes by means of insulin antibodies. Am J Med 31: 892-900

35. Heding LG, Persson B, Stangenberg M (1980) B-cell function in newborn infants of diabetic mothers. Diabetologia 19: 427-432

Received: 16 February 1988

and in revised form: 18 July 1988

Prof. J. Ludvigsson

Department of Paediatrics

University Hospital

S-58185 Linköping

Sweden 